AGRICULTURE AND BIOLOGY JOURNAL OF NORTH AMERICA

ISSN Print: 2151-7517, ISSN Online: 2151-7525, doi:10.5251/abjna.2011.2.4.724.728

(C) 2010, ScienceHu $\beta$, http://www.scihub.org/ABJNA

\title{
Haematological and Serum biochemical indices of growing rabbits fed bovine blood rumen - content mixture (BBRCM)
}

\author{
Mohammed, G., Igwebuike, J.U and Alade, N.K. \\ Department of Animal Science, University of Maiduguri, P.M.B. 1069, Maiduguri, Nigeria
}

\begin{abstract}
Forty-five crossbred rabbits (Dutch X New Zealand White) of mixed sexes age between 5 and 7 weeks were used for the study. They were divided into 5 groups of 9 rabbits each and used in a 10 week feeding trial to evaluated the blood biochemistry and haematology of growing rabbits fed bovine blood - rumen content mixture (BBRCM). The BBRCM which contained $35.4 \%$ crude protein and $25.10 \%$ crude fibre was included at 0, 10, 20, 30 and $40 \%$ levels in diets 1, 2, 34 and 5 respectively to replace groundnut in the diets. The hematological indices measured include packed cell volume (PCV), haemoglobin concentration $(\mathrm{Hb})$, red blood cells (RBC), white blood cells (WBC), mean corpuscular volume (MCV), mean haemoglobin concentration (MHC) and mean corpuscular haemoglobin concentration $(\mathrm{MCHC})$. The results indicated insignificant difference $(P>0.05)$ among the groups. Biochemical indices such as total protein, albumin, globulin, glucose, cholesterol, calcium and phosphorus were equally not effected ( $P>0.05)$ by treatment diets. These results underline the usefulness of BBRCM for rabbits feeding. The normal indices obtained in this study indicated that up to $40 \%$ BBRCM could be incorporated into the diets of growing rabbits without compromising the health status of the rabbits.
\end{abstract}

\section{Keywords: Bovine blood-rumen content mixture, growing rabbit, blood parameters \\ INTRODUCTION \\ Generally, both the haematological and biochemical components of the blood are influenced by the quantity and quality of feed and also the level of anti- nutritional elements or factors present in the feed (Akinmutimi, 2004). Biochemical components are sensitive to elements of toxicity in feeds. They can \\ be obtained at little or no cost, incorporating them into diets of growing rabbit will go a long way in reducing the feed cost and hence cost of production. Efforts therefore, were made in this study to assess the effect of feeding bovine blood - rumen content mixture on haematological and biochemical blood components of growing rabbits.} also be used to monitor protein quality of feeds. Haematological components of the blood are also valuable in monitoring feed toxicity especially with feed constituents that affect the formation of blood (Oyawoye and Ogunkunle, 1998).

(Mohammed et al. (2010) fed various levels pf bovine blood - rumen content mixture (BBRCM) to growing rabbits and recommended the inclusion of up to $40 \%$ BBRCM in their diets without adverse effect on their performance. However, effect of BBRCM on blood parameters is yet to be fully evaluated. The availability of the rumen content and blood in the Nigerian abattoirs and slaughter houses could be good sources of protein in rabbit diet if properly processed and harnessed (Swain, 1992). The need to maximize the economic benefits and minimize the disposal problems associated with rumen content and blood led to renewed interest in the investigation of these by - products for possible use as rabbit diet (NANV, 1994). Since blood and rumen content can

\section{MATERIALS AND METHODS}

Experimental site: This study was carried out at the rabbit unit of Teaching and Research Farm, University of Maiduguri. The geography and location is as described in Mohammed et al. (2005).

Management of the experimental stock: Forty-five (45) crossbred rabbits (Dutch $X$ New Zealand White) of mixed sexes with age ranging from 5 to 7 weeks were randomly allocated to five treatments in groups of 9 rabbits each. Each rabbit was housed individually in a cage cell. Prior to the experiment the were dewormed with ivomec injection $(0.2 \mathrm{ml}$ each rabbit).

Experimental diets: The composition of the experimental diets and blood bovine blood - rumen content mixture (BBRCM) are shown in Table 1. The diets contained $0,10,20,30$ and $40 \%$ BBRCM in diets 1 (control), 2, 3, 4 and 5 respectively. The diets supplied approximately $19 \%$ crude protein. 
Agric. Biol. J. N. Am., 2012, 2(4): 724-728

Table 1: Composition of the experimental diets

\begin{tabular}{|l|l|l|l|l|l|}
\hline & \multicolumn{5}{|l|}{ Diets / Treatments } \\
\hline Ingredient (\%) & 1 & 2 & 3 & 4 & 5 \\
\hline Maize & 40.98 & 39.12 & 37.41 & 35.24 & 24.35 \\
\hline Wheat offal & 17.00 & 17.00 & 17.00 & 17.00 & 17.00 \\
\hline BBRCM & 0.00 & 10.00 & 20.00 & 30.00 & 40.00 \\
\hline Groundnut cake & 23.37 & 15.23 & 6.94 & 2.11 & 0.00 \\
\hline Fish meal & 3.00 & 3.00 & 3.00 & 3.00 & 3.00 \\
\hline Groundnut haulms & 13.00 & 13.00 & 13.00 & 13.00 & 13.00 \\
\hline Bone meal & 2.00 & 2.00 & 2.00 & 2.00 & 2.00 \\
\hline Common salt (Nacl) & 0.50 & 0.50 & 0.50 & 0.50 & 0.50 \\
\hline Premix* & 0.15 & 0.15 & 0.15 & 0.15 & 0.15 \\
Total (kg) & 100 & 100 & 100 & 100 & 100 \\
Determine Analysis (\%) & & & & & \\
Crude protein (CP) & 19.20 & 18.74 & 18.84 & 17.70 & 18.83 \\
Crude fibre (CF) & 18.34 & 20.12 & 2.50 & 21.13 & 22.00 \\
Ether extract (EE) & 4.50 & 4.00 & 2.00 & 2.50 & 2.50 \\
Total Ash & 2.00 & 54.64 & 4.00 & 4.50 & 4.50 \\
Nitrogen free extract (NFE) & 55.96 & 2800.10 & 54.66 & 54.17 & 52.17 \\
ME (Kcal/kg) & 3061.48 & 2728.51 & 2815.94 & 2751.25 \\
\hline
\end{tabular}

BBRCM = Bovine blood-rumen content mixture

Premix (grow fast) manufacture by Animal care service consult (Nig) Ltd. Lagos, Supplying following

per kg of premix. Vitamin A, 5000,00 IU; Vitamin $D_{3} 800,000$ IU; Vitamin E 12,000mg; Vitamin

K 1,5000mg; Vitamin $B_{1}, 1,000 \mathrm{mg}$; Vitamin $B_{2} 2,000 \mathrm{mg}$, Vitamin $B_{6} 1,500 \mathrm{mg}$; Niacin 12,000mg;

pantothenic acid 20.00mg; Biotin 10.00mg; Vitamin $B_{12} 300.00 \mathrm{mg}$; folic acid 150,000mg; choline

60,000mg; manganese 10,000mg; iron 15,000mg, zinc 800.00mg; Copper 400.00mg; lodine 80.00mg;

cobalt 40mg; selenium $8,00 \mathrm{mg}$.

Blood collection: At week 10 of the experiment, blood samples were collected from three (3) rabbits per treatment for the determination of the haematological and serum biochemical indices. Samples were collected from the ear vein of the rabbits by venipunture using disposable needle (21 gauge needle) and syringes. The rabbits were fasted overnight (12hrs) and normally bled in the morning (7.00-8.00am) to avoid excessive bleeding. Fasting the rabbits was done to avoid the temporary elevation of many blood metabolities by feeding. The collection site was cleaned with alcohol and zylene applied to dilate the veins. Sterile cotton was used to cover the punctured vein after collection. The blood were collected in sample bottles containing dipotassium salt of ethylene diamine - tetra acetic acid (EDTA $-\mathrm{K}^{2+}$ ) which served as anticoagulant for haematology while the bottles for serum biochemical indices were free of EDTA $-\mathrm{K}^{2+}$.
The haematological analysis of blood samples were carried out at the Department of Veterinary Public Health, Faculty of Veterinary Medicine, University of Maiduguri, Nigeria using the routinely available clinical methods (Bush, 1975). The haematological indices determined were packed cell volume (PCV), haemoglobin concentration $(\mathrm{Hb})$, red blood cell (RBC) count or erythrocytes and white blood cell (WBC) count or leucocytes and differential counts. Others such as mean corpuscular haemoglobin $(\mathrm{MCH})$, mean corpuscular volume (MCV) and mean corpuscular haemoglobin concentration (MCHC) were obtained by calculation according to standard formulae (Schalm et al., 1975 and Jain, 1986) as shown below:

PCV $\times 10$

$\begin{aligned} \mathrm{MCV} & \left.=\mathrm{RBC} \text { count (in } 10^{6} / \mathrm{mm}^{3}\right) \\ \mathrm{MCH} & =\frac{\mathrm{Hb}(\mathrm{g} / \mathrm{dl}) \times 10}{\mathrm{RBC}\left(\mathrm{in} 10^{6} / \mathrm{mm}^{3}\right.} \\ \mathrm{MCHC} & =\frac{\mathrm{Hb}(\mathrm{g} / \mathrm{dl}) \times 100}{\mathrm{PCV} \%}\end{aligned}$


The other blood samples collected without coagulant were used to determine the biochemical components such as albumin, total protein, cholesterol, globulin, glucose, calcium and phosphorus using the methods described by other workers (Spencer and Price, 1997; Ajagbonna et al., 1999; Uko et al., 2000).

Statistical Analysis: All the data collected were subjected to analysis of variance (ANOVA) using a randomized complete block design (Steel and Torrie, 1980). Means were separated where applicable using the Duncan's multiple range test (Duncan, 1955).

\section{RESULTS AND DISCUSSION}

Haematological indices and Differential counts: Haematological indices and differential counts are presented in Table 2. All the haematological parameters (PCV, WBC, RBC and $\mathrm{Hb}$ ) were similar in all the treatments and within the normal ranges reported by Schalm et al. (1975) and Anon (1990). The PCV and $\mathrm{Hb}$ values were between 42 to $43 \%$ and 10.67 to $12.00 \mathrm{~g} / 100 \mathrm{ml}$ respectively. There were no significant difference $(P>0.05)$ among the treatment means. The PCV and $\mathrm{Hb}$ values obtained in this study are similar to the values reported by
Mohammed et al. (2005) who fed similar diets to growing rabbits. Hacbath et al. (1983) found that there is a strong influence of diets on haematological traits with PCV and $\mathrm{Hb}$ being very strong indicators of the nutritional status of animals. The values for WBC and RBC were between 2.08 to $3.28 \times 10^{3} / \mathrm{ul}$ and 3.59 to $4.74 \times 10^{6} / \mathrm{ul}$ respectively. There were no significant differences $(P>0.05)$ between the treatment groups for both WBC and RBC counts, $\mathrm{MCV}, \mathrm{MCH}$ and $\mathrm{MCHC}$. The values are close to the normal range of $60-73 \mathrm{fl}, 16.23 \mathrm{pg}$ and $26-34 \%$ for $\mathrm{MCV}, \mathrm{MCH}$ and $\mathrm{MCHC}$ respectively (Anon, 1980). No sign of ill-health or abnormal values were reported during the period of the experiment. Abnormal values may be an indication of anaemia (Bush, 1991; Onifade and Tewe, 1993; Abu et al, 1999).

The differential counts (\%) of monocytes, lymphocytes, basophils, neutrophils and eosinophils were also not significantly different $(P>0.05)$. The values are similar and fall within the normal range for health rabbits as reported by Ahamefule et al. (2006). The normal differential counts (\%) values portray the nutritional status of the rabbits, thus indicating adequate nourishment of the subjects (Chuch et al., 1984).

Table 2: Haematological indices in rabbits fed diets containing various levels of bovine blood - rumen content mixture (BBRCM)

\begin{tabular}{|c|c|c|c|c|c|c|c|}
\hline & \multicolumn{7}{|c|}{ Diets /Treatments } \\
\hline & $\mathrm{T}_{1}(0 \%)$ & $\mathrm{T}_{2}(10 \%)$ & $\mathrm{T}_{3}(20 \%)$ & $\mathrm{T}_{4}(30 \%)$ & $\mathrm{T}_{5}(40 \%)$ & Mean & SEM \\
\hline PCV (\%) & 42.67 & 44.00 & 42.33 & 44.33 & 42.67 & 43.20 & $1.83^{\mathrm{NS}}$ \\
\hline $\mathrm{Hb}(\mathrm{g} / 100 \mathrm{ml})$ & 10.33 & 10.67 & 11.00 & 12.00 & 11.33 & 11.07 & $0.79^{\mathrm{NS}}$ \\
\hline $\mathrm{RBC}\left(\times 10^{6} / \mathrm{mm}^{3}\right)$ & 4.58 & 4.71 & 3.59 & 4.70 & 4.72 & 4.46 & $0.73^{\mathrm{NS}}$ \\
\hline WBC $\left(\times 10^{3} / \mathrm{mm}^{3}\right)$ & 3.28 & 2.08 & 2.78 & 2.28 & 3.20 & 2.73 & $0.43^{\mathrm{NS}}$ \\
\hline MCV (fl) & 102.45 & 94.58 & 109.68 & 95.87 & 89.97 & 104.51 & $22.76^{\mathrm{NS}}$ \\
\hline $\mathrm{MCH}(\mathrm{pg})$ & 24.53 & 22.62 & 36.43 & 25.91 & 23.97 & 22.1 & $5.89^{\mathrm{NS}}$ \\
\hline $\mathrm{MCHC}(\%)$ & 23.84 & 24.34 & 25.95 & 27.05 & 26.70 & 25.58 & $1.81^{\mathrm{NS}}$ \\
\hline \multicolumn{8}{|c|}{ Differential counts (\%) } \\
\hline Monocytes & 2.00 & 3.33 & 2.67 & 3.67 & 1.67 & 2.67 & $0.72^{\mathrm{NS}}$ \\
\hline Basophils & 1.00 & 1.33 & 1.00 & 1.00 & 0.67 & 1.00 & $0.27^{\mathrm{NS}}$ \\
\hline Neutrophils & 43.33 & 45.67 & 47.67 & 39.00 & 42.33 & 43.60 & $4.45^{\mathrm{NS}}$ \\
\hline $\begin{array}{l}\text { Eosinophi } \\
\text { Lymphocytes }\end{array}$ & $\begin{array}{l}8.33 \\
45.33\end{array}$ & $\begin{array}{l}7.67 \\
37.67\end{array}$ & $\begin{array}{l}10.00 \\
41.67\end{array}$ & $\begin{array}{l}9.33 \\
47.00\end{array}$ & $\begin{array}{l}10.00 \\
47.00\end{array}$ & $\begin{array}{l}9.07 \\
43.80\end{array}$ & $\begin{array}{l}1.34^{\mathrm{NS}} \\
2.88^{\mathrm{NS}}\end{array}$ \\
\hline
\end{tabular}

NS = Not significant $(p>0.05) ;$ PCV = Packed cell volume; MCV = Mean corpuscular volume; $\mathrm{SEM}=$ Standard error of mean; $\mathrm{Hb}=$ Haemoglobin concentration; $\mathrm{MCH}=$ mean corpuscular haemoglobin; $\mathrm{BBRCM}=$ Bovine blood rumen content mixture;

$\mathrm{WBC}=$ White blood cell count; $\mathrm{MCHC}=$ Mean corpuscular haemoglobin concentration .

Serum biochemistry indices: The serum biochemical indices are presented in Table 3. The total protein, albumin, and globulin were not significantly different $(P>0.05)$ among the treatment groups. The value recorded for these parameters are 
within the acceptable ranges of $5.0-8.0 \mathrm{~g} / \mathrm{dl}, 2.5-$ $4.0 \mathrm{~g} / \mathrm{dl}$ and $2.15-2.85 \mathrm{~g} / \mathrm{dl}$ for total protein, albumin, and globulin respectively as reported by Anon (1980). The values obtained for total protein, albumin and globulin are generally influenced by total protein intake (Birt and Schuldt, 1982; Onifade and Tewe, 1993), the normal values obtained in this study indicated nutritional adequacy of dietary protein. Abnormal serum albumin usually indicate an alteration of normal systematic protein utilization. Awosanya et al. (1999) demonstrated the dependence of blood protein on the quality and quantity of dietary protein.
Glucose and cholesterol recorded in this experimental were not significantly different $(P>0.05)$ among the treatments and fall within the normal ranges reported by other workers (Anon, 1980; Onifade and Tewe, 1993). The calcium and phosphorus values compared favourably with normal ranges of $5.6-12.7 \mathrm{mg} / \mathrm{dl}$ and $2.3-6.9 \mathrm{mg} / \mathrm{dl}$ for calcium and phosphorus levels of rabbits respectively (Anon, 1980).

Table 3: Serum biochemical indices in rabbits fed diets containing various levels of Bovine blood rumen - content mixture (BBRCM)

\begin{tabular}{|l|l|l|l|l|l|l|l|}
\hline & \multicolumn{9}{|c|}{ Diets /Treatments } \\
\hline & $\mathrm{T}_{1}(0 \%)$ & $\mathrm{T}_{2}(10 \%)$ & $\mathrm{T}_{3}(20 \%)$ & $\mathrm{T}_{4}(30 \%)$ & $\mathrm{T}_{5}(40 \%)$ & Mean & SEM \\
\hline Albumin (g/dl) & 3.44 & 3.01 & 3.40 & 3.14 & 3.35 & 3.27 & $0.20^{\text {NS }}$ \\
\hline Total protein (g/dl) & 6.07 & 5.87 & 6.55 & 6.14 & 5.65 & 6.05 & $0.17^{\text {NS }}$ \\
\hline Cholesterol $(\mathrm{mg} / \mathrm{dl})$ & 39.31 & 38.00 & 41.14 & 37.00 & 40.14 & 39.12 & $1.59^{\text {NS }}$ \\
\hline Globulin $(\mathrm{g} / \mathrm{dl})$ & 2.64 & 2.86 & 2.28 & 2.35 & 2.78 & 2.58 & $0.32^{\text {NS }}$ \\
\hline Glucose $(\mathrm{mg} / \mathrm{dl})$ & 76.00 & 75.78 & 81.92 & 82.81 & 84.01 & 80.23 & $4.15^{\text {NS }}$ \\
\hline Calcium $(\mathrm{mg} / \mathrm{dl})$ & 5.40 & 5.50 & 5.53 & 6.13 & 6.17 & 5.75 & $0.39^{\text {NS }}$ \\
\hline Phosphorus $(\mathrm{mg} / \mathrm{dl})$ & 2.40 & 2.50 & 2.25 & 2.26 & 2.80 & 2.41 & $0.11^{\text {NS }}$ \\
\hline
\end{tabular}

NS = Not significant $(P>0.05)$

$\mathrm{SEM}=$ Standard error of means

\section{CONCLUSION}

The result of this study indicated that the levels (10 $40 \%$ ) of BBRCM included in the diets have no adverse effect on haematology and serum biochemical indices of the rabbits. However future studies are needed to evaluate the histopathology of some selected organs to further confirm the suitability and safety of BBRCM in rabbit diets.

\section{REFERENCES}

Abu, O.A, Igwebuike, J.U., Bikoi Bell, D., Mbaya, M. Y. and Umaru, R.S. (1999). Growth performance and economy of production of rabbits fed urea-treated or untreated rice husk-base diets. Proceeding $26^{\text {th }}$ Annual ASAP Conference 21 - 25 March, 1999. ilorin Pp. 140 - 143.

Ahamefule, F.O., Eduok, G.O. Usman, A. Amaefule, K.U., Obua, B.E, and Oguike S. A. (2006). Blood Biochemistry and Haematology of weaner Rabbits fed sun-dried, Ensilled and fermented cassava peel Based diets. Pakistan Journal of Nutrition 5(3). $248-253$.
Ajagbonna, O.P., Onifade, K.I. and Suleman, U. (1999). Haematological and biochemical changes in rats given extracts of Calotropis procera. Sokoto J. Vet. Sci. 36 42.

Akinmutimi, A.H. (2004). Evaluation of Sword bean (Canavalia gladiata) as an alternative feed resource for broiler chicken. Ph.D. Thesis. Michael Okpara University of Agriculture, Umudike, Nigeria.

Anon, (1980). Guide to the Care and Use of Experimental Animal Vol. 1. Canadian Council on Animal Care, Ottawa, Ontario, Canada. Pp. 85 - 90.

Awosanya, B., Joseph, J.R., Apata, D. F. and Agoola, M.A. (1999). Performance blood chemistry and carcass quality attributes of rabbits fed raw and processed pueraria seed meal. Trop. J. Anim. Sci. 2(2): 89 - 96.

Birth, D. F. and Schuldt, G.H. (1982). Effects of different source and level of protein fed to syrian hamsters on growth, protein utilization and selected blood proteins, Lab. Anim. Sci. 32:617 - 630.

Bush, B. M. (1991). Interpretation for Laboratory Manual. William Heinema Medical Book Ltd. London, UK. P. 447. 
Church, J.P,, Judd, J.T., Young, C.W., Kebay, J. L. and Kim, W.W. (1984). Relationship among dietary constituents and specific serum clinical components of subjects eating self selected diets. Anim. J. Clin. Nutr. 40: $1338-1344$.

Duncan, D.B. (1955). Multiple Range Test and Multiple Ftest Biometrics. 11: $1-2$.

Hackbarth, H; Buron, K. and Schimansley, G. (1983). Strain differences in inbred rats. Influence of strain and diet on haematological traits Lab Anim. 17: 7 12.

Jain, N.C. (1986). Veterinary haematology $4^{\text {th }}$ ed. Lea Febiger Publishers Philadelphia pp. 153 - 159.

Mohammed, G., Igwebuike, J.U. and Kwari, I.D. (2005). Nutrient digestibility, haematological indices and carcass measurements of rabbits fed graded levels of goat rumen content Global J. Agric Sci 4(1): 1 - 6.

Mohammed, G., Igwebuike, J.U and Alade, N.K. (2010). Performance of growing rabbits fed graded levels of bovine blood-rumen content mixture.

NAVN (1994). Nigeria Agro Vet News, Jan/Feb 1994, 1: 6.
Onifade, A.A. and Tewe, O.O. (1993). Alternative tropical energy feed in rabbit diets: Growth performance, diet digestibility and blood composition, World Rabbit Sci. 1(1): $17-24$

Oyawoye, E.O. and Ogunkunle, M. (1998). Physiological and biochemistry effects of Raw Jack beans on broiler. Proc. Nig. Soc. Anim. Prod. 23: 141 - 142.

Schalm, O.W., jain, N.C. and Carrol, E. (1975). Veterinary haematology $3^{\text {rd }}$ Edition Lea and Febiger, Philadelphia USA. Pp. $160-210$.

Steel, R. G.D. and Torrie, J.H. (1980). Principles and Procedures of Statistics. A Biometrical Aproach. $2^{\text {nd }}$ edition McGraw - Hill Book, Co; New York, USA. 633p.

Spencer, K. and Price, C.P. (1977). Chemical analysis of bilirubin in biological fluid. Annals of Clinical Biochemistry 14: $105-115$.

Swan, J.E. (1992). Animal by-product processing In: Encyclopedia of food Science Technology. Vol. 4 (Hui. .Y.H. ed). Pp. $42-49$

Uko, O.J., Ataja, A.M. and Tanko, H.B.(2000). Weight gain, haematology and blood chemistry of rabbit fed cereal offal. Sokoto J. Vet Sci. 2: 18 - 26. 